\title{
Faunal change and bathymetric diversity gradient in deep-sea prosobranchs from Northeastern Atlantic
}

\author{
CELIA OLABARRIA ${ }^{1,2}$ \\ ${ }^{1}$ Southampton Oceanography Centre, DEEPSEAS Benthic Biology Group, Empress Dock, South- \\ ampton SO14 3ZH, United Kingdom; ${ }^{2}$ Present address: Departamento de Ecoloxía e Bioloxía \\ Animal, Area Ecoloxía, Universidad de Vigo, Campus Lagoas-Marcosende, 36310 Vigo (Pontevedra), \\ Spain(e-mail: colabarria@uvigo.es; phone: +34-986-812587; fax: +34-986-812556)
}

Received 6 January 2005; accepted in revised form 11 July 2005

Key words: Deep sea, Diversity, Faunal turnover, Northeastern Atlantic, Porcupine Abyssal Plain, Porcupine Seabight, Prosobranchs

\begin{abstract}
Despite the plethora of studies, geographic patterns of diversity in deep sea remain subject of speculation. This study considers a large dataset to examine the faunal change and depth-diversity gradient of prosobranch molluscs in the Porcupine Seabight and adjacent Abyssal Plain (NE Atlantic). Rates of species succession (addition and loss) increased rapidly with increasing depth and indicated four possible areas of faunal turnover at about 700, 1600, 2800 and $4100 \mathrm{~m}$. Depth was a significant predictor of diversity, explaining nearly a quarter the variance. There was a pattern of decreasing diversity downslope from $\sim 250 \mathrm{~m}$ to $\sim 1500-1600 \mathrm{~m}$, followed by an increase to high values at about $4000 \mathrm{~m}$ and then again, a fall to $\sim 4915 \mathrm{~m}$. Processes causing diversity patterns of prosobranchs in the Porcupine Seabight and adjacent Abyssal Plain are likely to differ in magnitude or type, from those operating in other Atlantic areas.
\end{abstract}

\section{Introduction}

An increasing focus for biodiversity research in the deep sea has been to test for the existence of large-scale gradients in the diversity of marine softsediment fauna in deep sea (e.g. Rex 1981; Grassle 1989; Grassle and Macioleck 1992; Lambshead 1993; Rex et al. 1993; Dauvin et al. 1994; Patterson and Lambshead 1995; Lambshead et al. 2002). Molluscs form an ideal test assemblage for many hypotheses of diversity and its variation along environmental gradients because they are one of the more diverse and abundant groups of macrobenthos in the deep sea (Gage and Tyler 1991).

It is becoming increasingly recognised that adequate measures of diversity should include information on the 'relatedness' of the species rather than the number of species present and their relative abundances (Williams et al. 1991; Clarke and Warwick 1998). For example, assemblages with the same species richness may either comprise species which are closely related to one another taxonomically, or they may be more distantly related (Warwick and Clarke 
1995). Phylogenetic information and, consequently, the evolutionary history of taxa should be used to assess priority areas and to protect biological diversity. Conservation measures would give priority to taxonomically distinct taxa, i.e. species not closely related to each other, and taxa that show restricted areas of distribution, i.e. endemicity.

Standard diversity estimates depend on sampling effort (Hill 1973). Thus, any comparative study of biodiversity is sensitive to variations in sampling effort at different sites and/or times and methods are needed to reduce samples to a common size in order to compare species diversities. The rarefaction method (Sanders 1968), modified by (Hulbert 1971) has traditionally been the mainstay in assessing biodiversity in deep sea. Warwick and Clarke (1995) and Clarke and Warwick (1998) have defined a new diversity index to quantify the taxonomic diversity of a faunal assemblage capturing a component of the taxonomic relatedness of the species in each sample. This index measures the average path length along Linnean taxonomic classification of individuals of different species. It is a generalisation of the Simpson diversity index, incorporating information on taxonomic relationships within a sample into an index measuring species dominance (Rogers et al. 1999). One of the main characteristics of this index is that it is independent, on average, of the degree of sampling effort involved in the data collection. Thus, it can be compared across studies with differing levels of sampling intensity (Clarke and Warwick 1999).

This measure of taxonomic diversity has been applied to literature data on marine benthic assemblages (e.g. Warwick and Clarke 1995; Clarke and Warwick 1998) to illustrate the value of the index in assessment of environmental impacts. It has also been used in studies of diversity (e.g. Piepenburg et al. 1997; Hall and Greenstreet 1998; Rogers et al. 1999; Hooper et al. 2002; Woodd-Walker et al. 2002; Gambi et al. 2003; Tsurumi and Tunnicliffe 2003) providing additional insights of relevance to biodiversity assessment.

Meso and small-scale processes appear to be quite important in shaping patterns of deep-sea diversity because many species of macrofauna coexist in a mosaic of microhabitats (Grassle and Maciolek 1992). Nevertheless, patterns and processes of relatively small areas in deep sea are still poorly understood. Therefore, this study is focused on the Porcupine Seabight and adjacent Abyssal Plain region (NE Atlantic). This study considers a large dataset to examine the rate of turnover of prosobranch species with depth and the depth-diversity trend. In particular, the hypothesis tested was if there is a parabolic pattern of diversity as previously shown by other deepsea molluscs and invertebrates elsewhere (e.g. Rex 1981; Etter and Rex 1990; Etter and Grassle 1992; Rex et al. 1997). To test this hypothesis the relatively new taxonomic diversity index (Warwick and Clarke 1995) together with the rarefaction method (Hurlbert 1971) and the ShannonWiener $\log _{2}$-based index were used. 


\section{Material and methods}

Sampling area

The area of study, the Porcupine Seabight and the Porcupine Abyssal Plain, is located more than $200 \mathrm{~km}$ southwest of Ireland. The Seabight opens onto the Porcupine Abyssal Plain through a relatively narrow entrance to the southwest (site described in Howell et al. 2002; Olabarria 2005).

\section{Collection of samples}

A total of 71 epibenthic sledge samples were collected at depths between 150 and $4915 \mathrm{~m}$ over a period of 23 years (Figure 1).

The epibenthic sledge (Rice et al. 1982) has some shortcomings depending, to a large extent, on the faunal group being studied (see review in Howell et al. 2002). For example, mobile benthopelagic forms, small animals and deeply

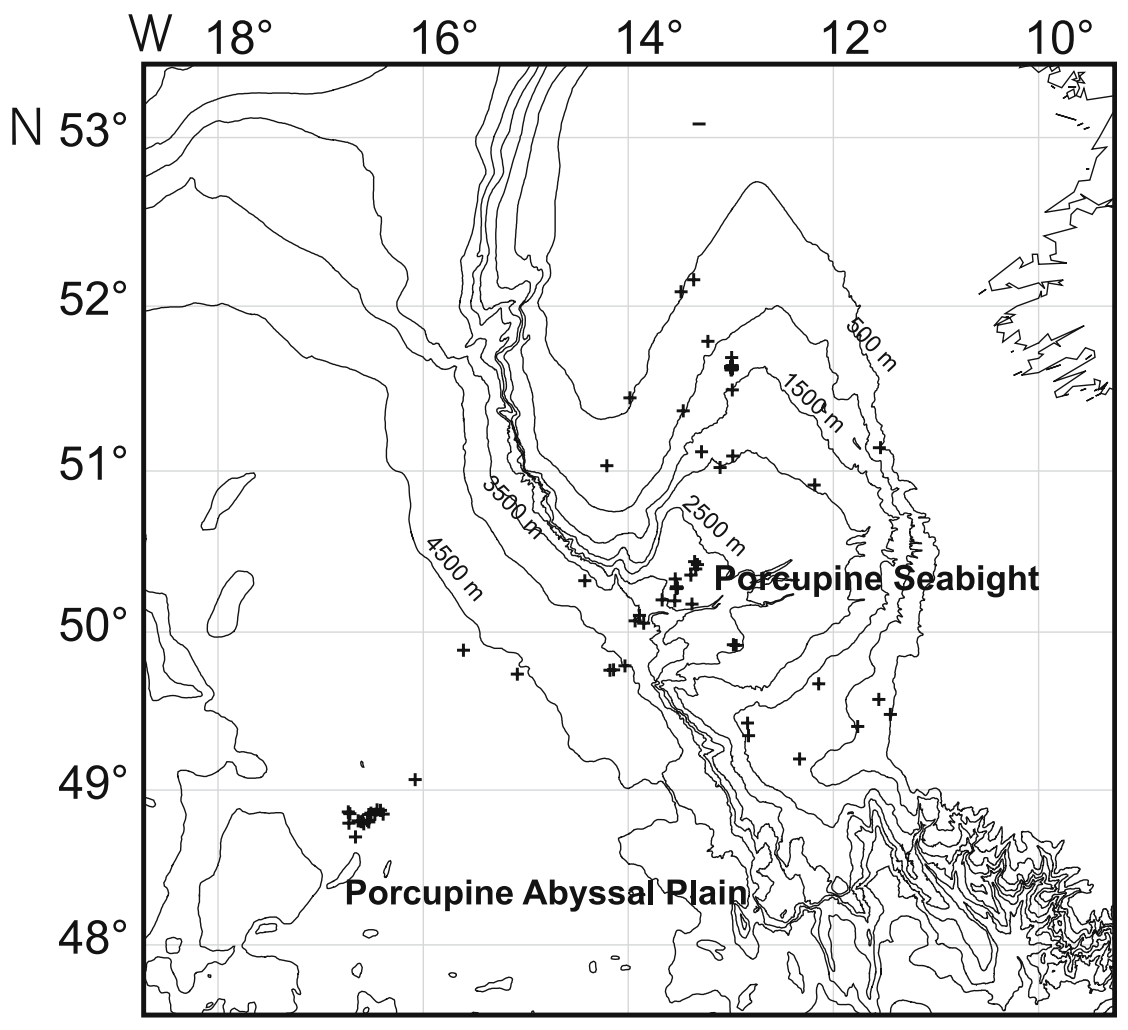

Figure 1. Location of the study area and sampling stations. 
buried organisms are sampled less effectively than other groups. However, gastropods are generally slow moving, epibenthic macrofauna and such as are considered to be sampled quite effectively.

The area of the seabed sampled was calculated from the width of the sledge opening and distance of the sampling run over the seabed. Samples were sorted on deck, washed through a 1-mm mesh sieve, fixed in borax-buffered $4 \%$ formaldehyde in seawater and then preserved in $80 \%$ alcohol. Specimens were identified to species level when possible. Number of species were counted per sample and standardised to the number of individuals per $100 \mathrm{~m}^{2}$.

\section{Analysis of data}

\section{Bathymetric distribution}

To analyse the bathymetric distributions of species, samples were grouped into $100 \mathrm{~m}$ depth bands. The range of species was assumed to be continuous between the depths of first and last occurrence. To investigate species change with depth, data were used to give depths of first and last occurrence of species. These values were then used to produce plots of species addition, loss and succession with increasing depth in order to identify possible boundaries where faunal turnover occurs (Howell et al. 2002); (Olabarria 2005). A non-metric multi-dimensional scaling using the Bray-Curtis similarity coefficient applied to the standardised and square root-transformed data was performed. Then the MDS $x$ value output was plotted against depth to identify areas of faunal change (Howell et al. 2002). In addition, a Spearman rank correlation coefficient was calculated for the $x$ value output of the MDS plot (change in species composition) and depth.

Analysis of diversity

Taxonomic diversity $(\Delta)$ was calculated following Warwick and Clarke (1995):

$$
\Delta=\left[\Sigma \Sigma_{i<j} \omega_{i j} x_{i} x_{j}\right][n(n-1) 2],
$$

where $\mathrm{x}_{i}=(i=1, \ldots, s)$ is the abundance of the $i$ th species of the total number of species, $s, n\left(=\Sigma_{i} x_{i}\right)$ is the total number of individuals in the sample and $\omega_{i j}$ is the weight given to the path length linking species $i$ and $j$ in the taxonomical classification. Therefore, taxonomic diversity is the average path length between any randomly chosen individuals from the sample. This index was applied to square root-transformed data.

Four taxonomic levels (species, genus, family and superfamily) were included in the analyses. The weights used were the simplest possible ones: $\omega=1$ (different species), 2 (different genera), 3 (different families) and 4 (different superfamilies). Taxonomic weights were allocated according to the classification of deep-sea prosobranchs by Bouchet and Warén (1980, 1985, 1986, 1993) and Rosenberg (1998). 
Furthermore, species diversity was estimated using the rarefaction method (Hurlbert 1971). This method has been used extensively as a measure of marine species diversity at small and large spatial scales (see Gray 2000 for review). Values for the expected number of species in a sample of 30 individuals (ES (30)) were extracted from the PRIMER programme. The ES (30) value was used in this study because of the patchy distribution and low abundance of many of the species observed. In addition, the Shannon-Wiener $\log _{2}$-based index was used.

Diversity indices obtained were plotted against water depth and regression lines calculated to estimate bathymetric gradients.

\section{Results}

Faunistic composition and its variation with depth

A total of $\sim 108,693$ individuals belonging to 88 species and 24 families were collected (Table 1). Of these, the family Turridae was the most diverse with 20 species (Figure 2a). However, this diversity was not correlated with abundance as the families Rissoidae and Columbellidae were more numerous than the Turridae (Figure 2b). This was due to the high number of Benthonella tenella (Jeffreys) and Amphissa acutecostata (Philippi) from the families Rissoidae and Columbellidae, respectively. The abundances of these species accounted for more than $95 \%$ of the total number of individuals in both of these families.

Although several species showed very restricted depth ranges, i.e. occurrence at a particular depth or depth range less than $300 \mathrm{~m}$ (e.g. Bathyacmaea sp1, Lissotesta sp1, Galeodea rugosa, Hemiaclis obtusa; Table 1), most species $(\sim 60 \%)$ showed broad bathymetric ranges (e.g. Calliotropis ottoi, Lamellitrochus sp1, Cerithiella metula, Amauropsis sphaeroides, Claviscala richardi; Table 1). Few species' ranges extended over more than $3000 \mathrm{~m}$ (e.g. C. ottoi, A. porcupinae, B. tenella, Oocorys sulcata, Troschelia berniciensis). Two species, A. porcupinae and Pleurotomella packardi from the families Rissoidae and Turridae, respectively, had the widest bathymetric ranges. Families Muricidae, Buccinidae and Cassidae also showed broad bathymetric ranges (Table 1). Although there was a gradual replacement of species with depth many species overlapped in their depth ranges, i.e. approximately $67 \%$ of species coexisted in the 1100-2800 depth range. A low percentage of species $(\sim 19 \%)$ occurred deeper than $3000 \mathrm{~m}$, whereas $\sim 30 \%$ of species occurred shallower than $2000 \mathrm{~m}$ (Table 1). In general, most of species showed a patchy distribution through their depth range, often occurring, in any great abundance, only over a very narrow depth range. The depth range over which a species was present at maximum abundance did not always occur in the middle of its total depth range. About $40 \%$ of species had distributions skewed to the opposite ends of their depth ranges (see Table 1). 
Table 1. Depth distribution of prosobranchs from the Porcupine Seabight and adjacent Abyssal Plain.

\begin{tabular}{|c|c|c|c|}
\hline Family & Species & $\begin{array}{l}\text { Depth } \\
\text { range }\end{array}$ & $\begin{array}{l}\text { Depth of } \\
\text { maximum } \\
\text { abundance }\end{array}$ \\
\hline Acmaeidae & Bathyacmaea sp nc & $1400-1500$ & $1400-1500$ \\
\hline Scisurellidae & Scisurella $\mathrm{sp}$ nc & $1300-4900$ & $1300-1400$ \\
\hline \multirow[t]{4}{*}{ Trochidae } & Calliotropis ottoi Philippi, 1844 & $1200-4900$ & $2600-2700$ \\
\hline & Calliostoma sp1 c & $100-200$ & $100-200$ \\
\hline & Calliostoma $\mathrm{sp} 2 \mathbf{c}$ & $4800-4900$ & $4800-4900$ \\
\hline & Lamellitrochus sp & $1300-5000$ & $1300-1400$ \\
\hline \multirow[t]{4}{*}{ Skeneidae } & Granigyra sp nc & $1200-1400$ & $1200-1300$ \\
\hline & Lissotesta $\mathrm{sp} \mathbf{n c}$ & $1200-1300$ & $1200-1300$ \\
\hline & Cyclostrema sp1 nc & $1300-4000$ & $1300-1400$ \\
\hline & Cyclostrema $\mathrm{sp} 2 \mathbf{n c}$ & $2000-3700$ & $1900-2000$ \\
\hline Seguenziidae & Seguenziella sp nc & $1600-2900$ & $1600-1700$ \\
\hline \multirow[t]{3}{*}{ Cerithiopsidae } & Cerithiella amblytera (Watson, 1880) c & $4000-4100$ & $4000-4100$ \\
\hline & C. metula (Lovén, 1846) c & $900-2700$ & $1300-1400$ \\
\hline & Laiocochlis sinistrata (Nyst, 1835) c & $1283-1400$ & $1300-1400$ \\
\hline Turritellidae & Turritella sp nc & $100-200$ & $100-200$ \\
\hline \multirow[t]{4}{*}{ Rissoidae } & $\begin{array}{l}\text { Alvania porcupinae Gofas and } \\
\text { Warén, } 1982 \text { nc }\end{array}$ & $100-4900$ & $100-200$ \\
\hline & Alvania cimicoides (Forbes, 1844) nc & $100-200$ & $100-200$ \\
\hline & Alvania subsoluta (Aradas, 1847) nc & $700-1200$ & $700-800$ \\
\hline & Benthonella tenella (Jeffreys, 1869) nc & $400-4900$ & $1100-140$ \\
\hline Aporrhaidae & Aporrhais serresianus (Michaud, 1828) nc & $400-2700$ & $900-1200$ \\
\hline \multirow[t]{2}{*}{ Capulidae } & Capulus simplex Locard, 1898 nc & $2700-2800$ & $2700-2800$ \\
\hline & Torellia delicata (Philippi, 1844) nc & $1100-2800$ & $1100-1200$ \\
\hline Hipponicidae & Leptonotis sp? nc & $3600-3700$ & $3600-3700$ \\
\hline Haloceratidae & Haloceras tricarinata (Jeffreys, 1885) c & $4000-4100$ & $4000-4100$ \\
\hline Velutinidae & Calyptoconcha pellucida (Verrill, 1880) c & $1200-1300$ & $1200-1300$ \\
\hline \multirow[t]{4}{*}{ Naticidae } & Cryptonacia affinis (Gmelin, 1791) c & $1400-2700$ & $1900-2000$ \\
\hline & Amauropsis sphaeroides (Jeffreys, 1877) c & $2300-4900$ & $2300-2400$ \\
\hline & Polinices obtusa (Jeffreys, 1885) c & $100-3600$ & $1900-2000$ \\
\hline & P. subplicata (Jeffreys, 1885) c & $1200-3100$ & $1300-1400$ \\
\hline \multirow[t]{2}{*}{ Cassidae } & Oocorys sulcata Fischer, 1883 c & $400-4100$ & $2600-2700$ \\
\hline & Galeodea rugosa (Linnaeus, 1771) c & 400 & 400 \\
\hline \multirow[t]{3}{*}{ Epitoniidae } & Eccliseogyra sp c & $3900-4000$ & $3900-4000$ \\
\hline & $\begin{array}{l}\text { Epitonium dallianum (Verrill and } \\
\text { Smith, 1880) c }\end{array}$ & $100-1200$ & $100-200$ \\
\hline & $\begin{array}{l}\text { Claviscala richardi (Dautzenberg and } \\
\text { de Boury, 1897) c }\end{array}$ & $700-4000$ & $700-800$ \\
\hline Acliidae & Aclis sarsi (Dautzenberg and Fischer, 1912) & $700-1200$ & $1100-1200$ \\
\hline \multirow[t]{7}{*}{ Eulimidae } & Eulima bilineata Alder, 1848 c & $1200-2800$ & $1200-1300$ \\
\hline & Haliella stenostoma (Jeffreys, 1858) & $700-1300$ & $700-800$ \\
\hline & $\begin{array}{l}\text { Rectilabrum lanceolatum Bouchet and } \\
\text { Warén, } 1986 \text { c }\end{array}$ & $4000-4100$ & $4000-4100$ \\
\hline & $\begin{array}{l}\text { Melanella densicostata Bouchet and } \\
\text { Warén, } 1986 \text { c }\end{array}$ & $3600-3700$ & $3600-3700$ \\
\hline & M.cf charissa (Jordan, 1895) c & $3600-4100$ & $3600-3700$ \\
\hline & M. jeffreysi (Tyron, 1886) c & $1100-1400$ & $1300-1400$ \\
\hline & M. lucida (Verrill, 1884) c & $1200-1400$ & $1200-1300$ \\
\hline
\end{tabular}


Table 1. (Continued).

\begin{tabular}{|c|c|c|c|}
\hline Family & Species & $\begin{array}{l}\text { Depth } \\
\text { range }\end{array}$ & $\begin{array}{l}\text { Depth of } \\
\text { maximum } \\
\text { abundance }\end{array}$ \\
\hline & $\begin{array}{l}\text { M. martynjordani } \\
\text { (Jordan, 1895) c }\end{array}$ & $2700-2800$ & $2700-2800$ \\
\hline & Melanella sp1 c & $4800-5000$ & $4800-4900$ \\
\hline & Melanella sp2 c & $900-1200$ & $1100-1200$ \\
\hline & $\begin{array}{l}\text { Pisolamia brychia } \\
\text { (Watson, 1883) c }\end{array}$ & $4600-4900$ & $4600-4700$ \\
\hline & Eulitoma $\mathrm{sp} \mathbf{c}$ & $1100-1200$ & $1100-1200$ \\
\hline & Hemiaclis obtusa & $2700-2800$ & $2700-2800$ \\
\hline & Bouchet and & & \\
\hline & Warén, 1986 c & & \\
\hline \multirow[t]{3}{*}{ Muricidae } & Trophon barviciensis (Johnston, 1825) c & $100-200$ & $100-200$ \\
\hline & T. dabneyi Dautzenberg, 1889 c & $1200-1300$ & $1200-1300$ \\
\hline & Trophon sp c & $100-400$ & $100-200$ \\
\hline \multirow{12}{*}{ Buccinidae } & Liomesus ovum (Turton, 1825) c & $700-800$ & $700-800$ \\
\hline & $\begin{array}{l}\text { Buccinum abyssorum Verrill and } \\
\text { Smith, } 1884 \text { c }\end{array}$ & $700-3600$ & $700-800$ \\
\hline & Troschelia berniciensis (King, 1846) c & $100-4000$ & $900-1100$ \\
\hline & Neptunea antiqua (Linnaeus, 1758) c & $3500-3600$ & $3500-3600$ \\
\hline & N. contraria (Linnaeus, 1771) c & $700-2800$ & $700-800$ \\
\hline & Mohnia abyssorum (Fischer, 1883) c & $1900-4700$ & $3500-3600$ \\
\hline & Mohnia sp c & $700-4900$ & $700-800$ \\
\hline & Turrisipho sp c & $100-2800$ & $900-1000$ \\
\hline & Belomitra quadruplex (Watson, 1882) c & $1600-4100$ & $3900-4000$ \\
\hline & Colus islandicus (Mohr, 1786) c & $700-5000$ & $3000-3100$ \\
\hline & C. jeffreysianus (Fischer, 1868) c & $700-2400$ & $2000-2100$ \\
\hline & C.cf latericius (Möller, 1842) c & $700-900$ & $700-800$ \\
\hline \multirow[t]{2}{*}{ Columbellidae } & Amphissa acutecostata (Philippi, 1844) c & $700-2800$ & $1100-1300$ \\
\hline & Mitrella nitidulina (Locard, 1897) c & $2700-2800$ & $2700-2800$ \\
\hline Volutomitridae & Volutomitra sp & $700-800$ & $700-800$ \\
\hline \multirow[t]{2}{*}{ Cancellaridae } & Admete viridula (Fabricius, 1780) c & $1900-2000$ & 1900-2000 \\
\hline & Iphinopsis alba Bouchet and Warén, 1985 c & $1300-3600$ & $2600-2700$ \\
\hline \multirow[t]{16}{*}{ Turridae } & Spirotropis monterosato (Locard, 1897) c & $700-2700$ & $700-800$ \\
\hline & Micropleurotoma melvilli (Sykes, 1906) c & $1300-1400$ & $1300-1400$ \\
\hline & Irenosyrinx hypomela (Dall, 1889) c & $1300-4000$ & $2700-2800$ \\
\hline & Leucosyrinx verrilli (Dall, 1881) c & $2600-2800$ & $2600-2700$ \\
\hline & Typhlomangelia nivalis (Lovén, 1846) c & $200-2800$ & $1300-1400$ \\
\hline & Drilliola pruina (Watson, 1881) c & $1900-3600$ & $1900-2000$ \\
\hline & Pleurotomella packardi Verrill, 1872 c & $100-5000$ & $1300-1400$ \\
\hline & Benthomangelia antonina (Dall, 1881) c & $2600-4000$ & $3900-4000$ \\
\hline & B. decapitata Bouchet and Warén ,1980 c & $2000-4900$ & $3900-4000$ \\
\hline & B. macra (Watson, 1881) c & $2800-3700$ & $2800-2900$ \\
\hline & Gymnobela frielei (Verrill, 1885) c & $700-4900$ & $3900-4000$ \\
\hline & $\begin{array}{l}\text { G. subaraneosa (Dautzenberg and } \\
\text { Fischer, 1896) c }\end{array}$ & $1100-4900$ & $2700-2800$ \\
\hline & Theta of vayssieri (Dautzenberg, 1925) c & $4800-4900$ & $4800-4900$ \\
\hline & T. lyronuclea (Clarke, 1959) c & $3900-5000$ & $3900-4000$ \\
\hline & Bathybela nudator (Locard, 1897) c & $4600-5000$ & $4600-4700$ \\
\hline & Oenopota ovalis (Friele, 1877) c & $1600-2000$ & $1600-1700$ \\
\hline
\end{tabular}


Table 1. (Continued).

\begin{tabular}{|c|c|c|c|}
\hline Family & Species & $\begin{array}{l}\text { Depth } \\
\text { range }\end{array}$ & $\begin{array}{l}\text { Depth of } \\
\text { maximum } \\
\text { abundance }\end{array}$ \\
\hline & O. tenuicostata (Sars, 1878) c & $1300-3100$ & $1300-1400$ \\
\hline & Teretia teres (Forbes, 1844) c & $100-1200$ & $700-800$ \\
\hline & Lusitanops cf lusitanica (Sykes, 1906) c & $1600-2000$ & $1600-1700$ \\
\hline & $\begin{array}{l}\text { Lusitanops cf sigmoidea } \text { Bouchet and } \\
\text { Warén, } 1980 \text { c }\end{array}$ & $4000-5000$ & $4800-4900$ \\
\hline
\end{tabular}

Feeding types (carnivores/ non-carnivores) were also indicated following Valentine et al. (2002). The category of carnivores includes active predators and scavengers on animal tissue, consumers of sessile animals, and ectoparasites. c, carnivores; nc, non-carnivores.

Mean abundance for prosobranchs as a whole showed a peak abundance between $\sim 1100$ and $1300 \mathrm{~m}\left(437.87 \pm 95.47\right.$ ind. $\left.100 \mathrm{~m}^{2}\right)$, but mainly due to the high abundance of $B$. tenella. Seven species, B. tenella, A. acutecostata, Aporrhais serresianus, Polinices obtusa, P. packardi, Gymnobela subaraneosa and C. ottoi, presented high densities in the area of study. P. packardi, $B$. tenella and $P$. obtusa presented their maxima abundance at mid-bathyal zone, i.e. between $\sim 1100$ and $1700 \mathrm{~m}$ (Table 1). In contrast, A. serresianus presented maximum abundance between $\sim 900$ and $1200 \mathrm{~m}$, whereas $A$. acutecostata and $C$. ottoi showed peaks of abundance at low continental slope, i.e. between $\sim 2600$ and $2800 \mathrm{~m}$.

The rate of species succession (addition and loss) increased rapidly with increasing depth (Figure 3). Moreover, a Spearman rank correlation of depth and MDS $x$-axis co-ordinates (a one dimensional measure of species change) gave a coefficient of $0.74(p<0.01)$ (Figure 4), indicating that samples were grouped by depth. The overall rate of faunal change was greater at shallower than deeper waters (Figure 4). Four possible areas of faunal turnover at about 700, 1600, 2800 and $4100 \mathrm{~m}$ were identified (Figure 3). In particular, the zone ranging from the shelf break to $\sim 700 \mathrm{~m}$ showed a rapid turnover with an abrupt step-like change in rate of species accumulation at about $700 \mathrm{~m}$, i.e. 15 species added (Figure 3). Most of these species had restricted depth distributions apart from Claviscala richardi, Buccinum abyssorum, Colus islandicus and Gymnobela frielei (Table 1). From $\sim 700 \mathrm{~m}$ to $\sim 1600 \mathrm{~m}$ species succession was also very rapid with high rate of species addition, i.e. 28 species (Figure 3 ) and species loss, i.e. 15 species. In fact, about $23 \%$ of total species number was added between $\sim 700$ and $1600 \mathrm{~m}$. Below $\sim 1600 \mathrm{~m}$ the rate of species addition was more gradual, whereas the rate of species loss was rapid showing two peaks at $\sim 2800 \mathrm{~m}$ and $\sim 4100 \mathrm{~m}$ (Figure 3 ). The zone below $\sim 4000 \mathrm{~m}$ was marked by the presence of typical abyssal species, i.e. Pisolamia brychia, Theta vayssieri, Bathybela nudator or Lusitanops sigmoidea (see Table 1). 

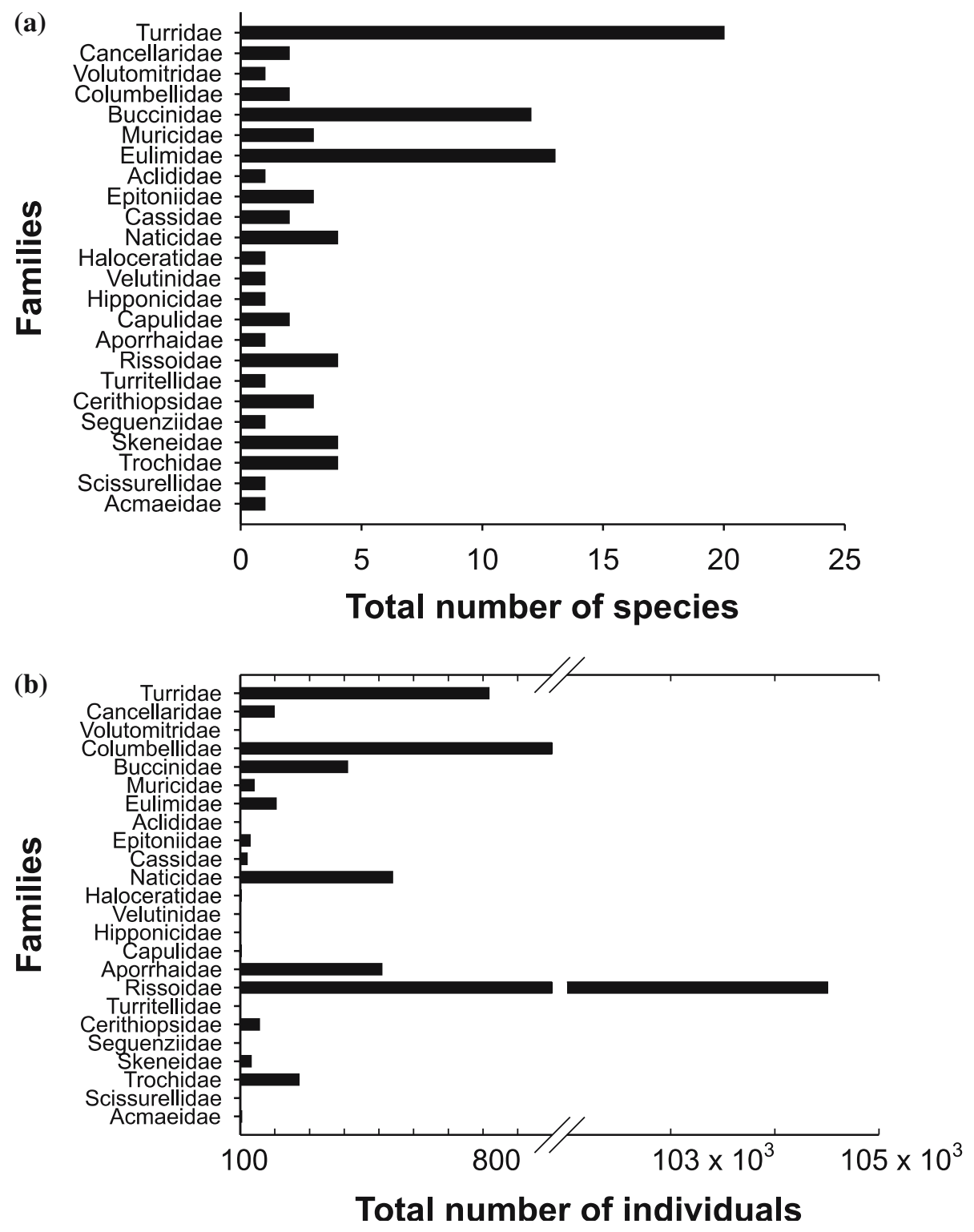

Figure 2. (a) Distribution of total number of species per family; (b) distribution of total number of individuals per family.

Bathymetric gradient of diversity

Taxonomic diversity index $(\Delta)$

There was a pattern of decreasing diversity downslope from $\sim 250 \mathrm{~m}$ to $\sim 1400$ $1600 \mathrm{~m}$, followed by an increase to high values at about $4000 \mathrm{~m}$ and then 


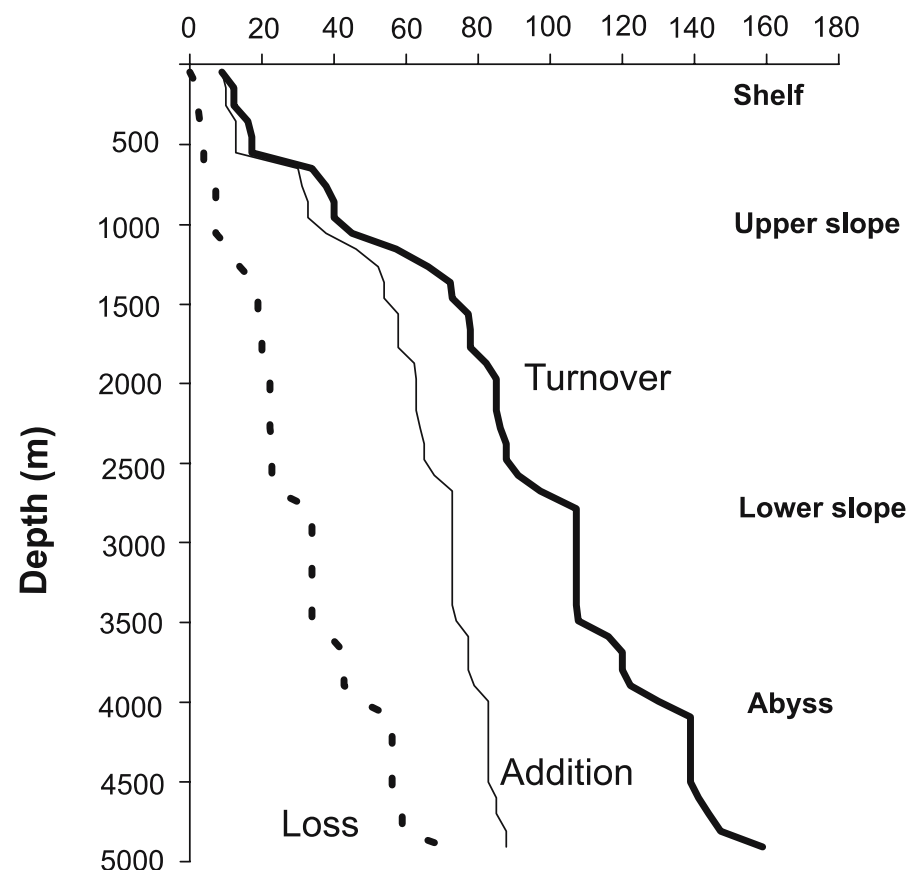

Figure 3. Cumulative addition and loss of species with depth from full dataset. Turnover (addition plus loss) of species is also plotted.

again, a fall to $\sim 4915 \mathrm{~m}$ (the lower depth limit in this study) (Figure 5a). This trend of diversity with depth was significant and was represented by a three degree polynomial relationship $\left(r^{2}=0.321 ; F_{3,69}=8.18, p<0.001\right)$.

Rarefaction method

Results were quite similar to those obtained by using the taxonomic diversity index. Depth did account for a significant portion of the variation in diversity $\left(r^{2}=0.262 ; F_{3,24}=3.82, p<0.05\right)$. Diversity decreased up to minimum values at $\sim 1500 \mathrm{~m}$ followed by an increase up to high values at $\sim 4000 \mathrm{~m}$ (Figure $5 \mathrm{~b}$ ).

Shannon-Wiener index

This index showed the same trend than the other indices, but weaker (Figure 5c). Depth only accounted for $\sim 19 \%$ of variance in diversity $\left(r^{2}=0.187\right.$; $\left.F_{3,69}=5.30, p<0.01\right)$.

\section{Discussion}

\section{Faunistic composition and depth}

The family Turridae was the most diverse and it had the broadest bathymetric range, being observed over the whole sampling range, i.e. $\sim 150-4915 \mathrm{~m}$. 


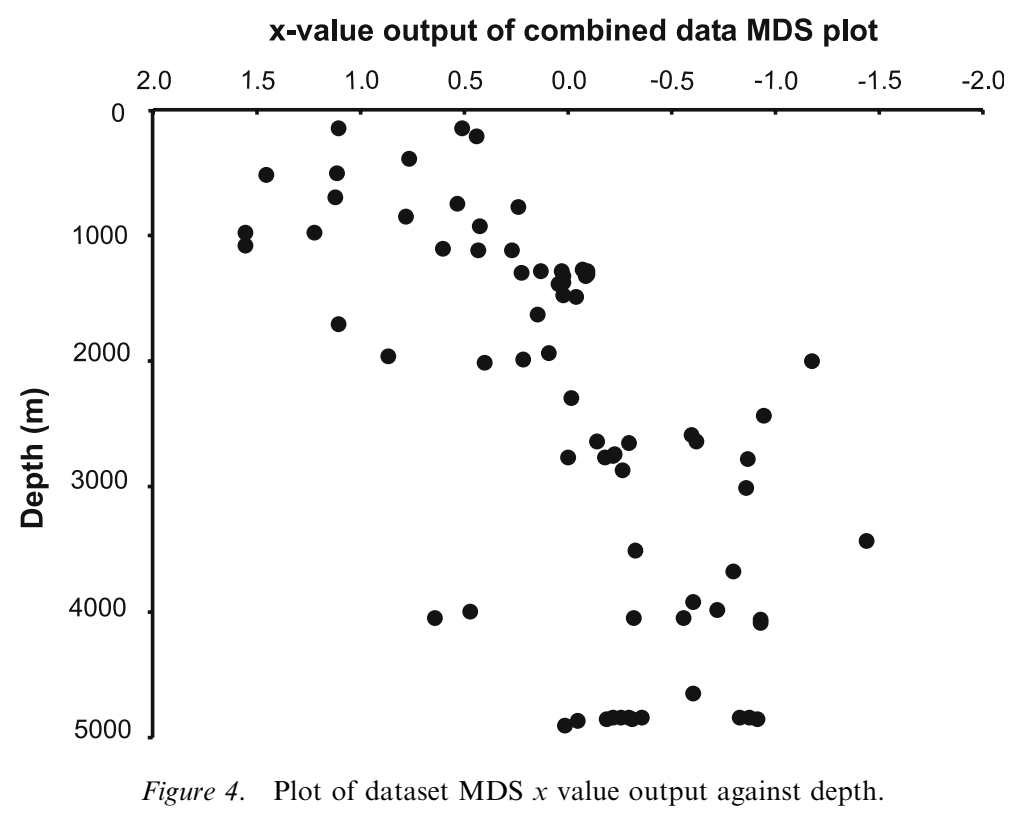

Bearing in mind that the highest abundances of the families Rissoidae and Columbellidae were only due to two species, B. tenella and A. acutecostata, family Turridae occupied the third position in terms of abundance. The specific dominance of the family Turridae in this area agreed with findings in other deep-sea areas (Bouchet and Warén 1980) and also confirmed the observations by Rex et al. (1999) that turrids become increasingly abundant in the deep sea. Furthermore, the high abundances of $B$. tenella as found in the study area (i.e., in $45 \%$ of samples) have also been found in the Western Atlantic (Rex et al. 1979; Rex and Etter 1990). A planktotrophic development with ontogenetic migration gives this species high potential for large-scale dispersal (Rex and Etter 1990). This may, in part, explain the species' wide geographic range and abundance.

Many invertebrates are known to form aggregations in deep sea (e.g. Billett 1991; Gage and Tyler 1991; Howell et al. 2002). These aggregations may be for feeding and/or reproduction (Howell et al. 2002). The patchy distribution of prosobranchs in this area suggests that this pattern might be related to factors operating at local scale (e.g. food availability, reproduction and biological interactions) rather than global factors operating a larger scale, i.e. temperature, pressure, currents. Nevertheless, water mass structure and depth of the permanent thermocline have been proposed as possible factors controlling megafaunal zonation in Porcupine Seabight (i.e. Billett 1991; Howell et al. 2002). Furthermore, flow velocities and organic matter supply have been found to play an important role in structuring the benthic community on a very close area, Goban Spur (Flach et al. 1998). Topographical features of Porcupine Seabight, i.e. canyon-like topography, might also exert a strong effect in 

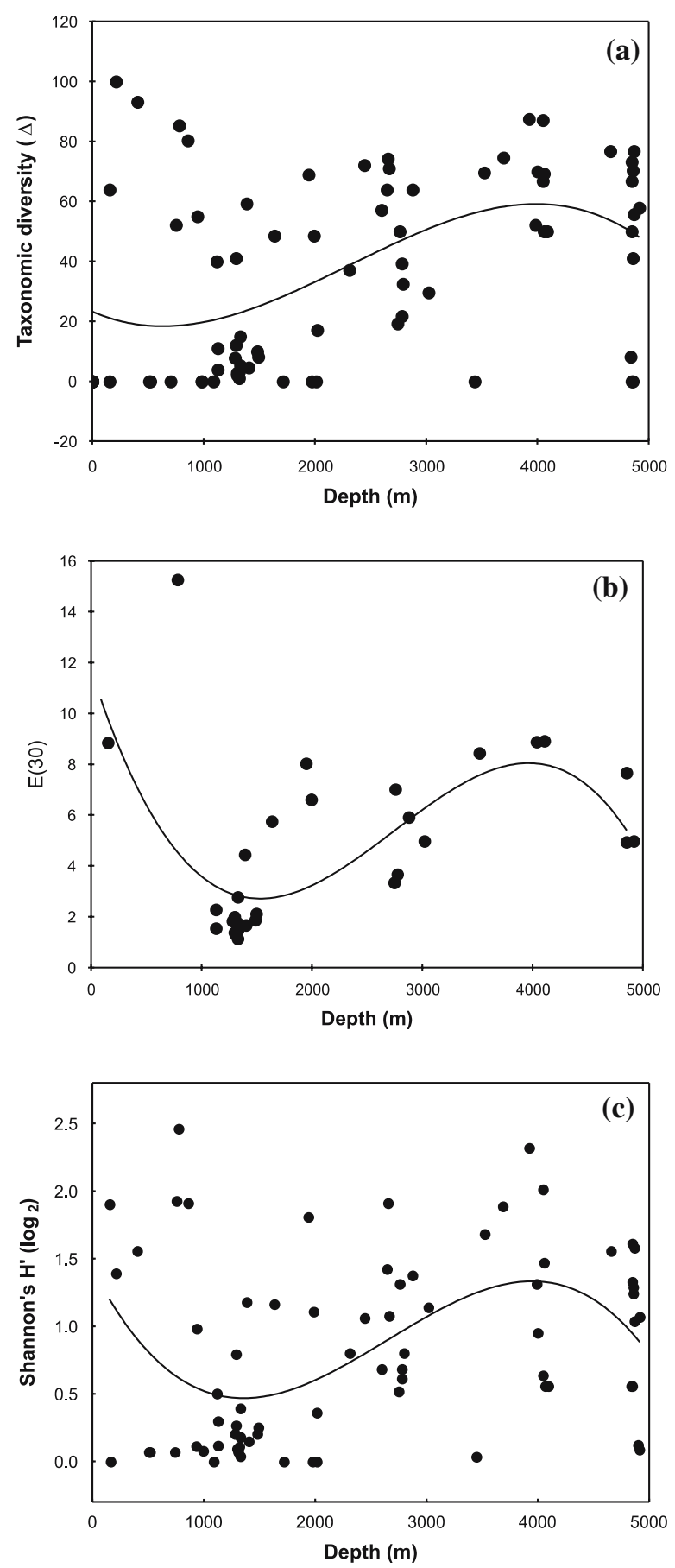
Figure 5. Bathymetric variation of diversity in deep-sea prosobranchs from Porcupine Seabight and adjacent Abyssal Plain. The solid line is the regression line. (a) Graph shows variation of taxonomic diversity $(\Delta)$ with depth; $y=69.581-0.083 x+4.091 \mathrm{E}-05 x^{2}-5.11 \mathrm{E}-09 x^{3}$ $\left(r^{2}=0.321 ; F_{3,69}=8.18, p<0.001\right)$. (b) Graph shows variation of $\mathrm{E}\left(S_{30}\right)$ with depth; $y=12.764-0.0143 x+6.241 x^{2}-7.404 x^{3}\left(r^{2}=0.262 ; F_{3,24}=3.82, p<0.05\right)$. (c) Graph shows variation of $\mathrm{H}^{\prime}$ with depth; $y=1.424-0.0015 x+7.89 \mathrm{E}-07 x^{2}-9.921 \mathrm{E}-11 x^{3}$.

patterns of distribution of prosobranchs (see Olabarria 2005). In fact, the fauna of canyons can show different patterns of distribution than the fauna of adjacent non-canyon areas at the same depth (Gage et al. 1995). In addition, we have to bear in mind that temporal variability, i.e. seasonal and/or interannual, in abundance of species might have affected the patterns observed in this study. For example, species such as B. tenella, A. acutecostata, P. packardi and $A$. serresianus had peaks of abundances at certain depths between 1979 and 1982 as those shown by bivalves in the same area (Olabarria 2005). These changes in abundances might be related to temporal variations in quality and/ or quantity of food (e.g. Danovaro et al. 1999; Billet et al. 2001).

Despite many species exhibiting quite broad bathymetric ranges, their depth distributions were more restricted than those found for other molluscs such as bivalves in the same area (Olabarria 2005). More restricted distributions for gastropods in comparison to other deep-sea invertebrates have been also reported elsewhere (e.g. Sanders and Grassle 1971; Rex 1981, 1983; Allen and Sanders 1996). There was also a rapid rate of species turnover with depth (Figures 3 and 4) as previously shown by gastropods (Rex 1977). Trophic factors exert an influence on species zonation through competitive interactions (Rex 1977). Rates of zonation increase with trophic level (or size) (Rex 1977; Cartes and Carrason 2004) so faunal replacement with depth is more rapid among predators than infaunal deposit-feeders such as polychaetes and bivalves (Rex 1977). This model was also supported in this study by the fact that there was an increase in the carnivores/non-carnivores ratio with increasing depth $\left(r^{2}=0.20 ; F_{1,53}=5.46, p<0.01\right)$. A rapid rate of turnover with depth would be related to an increase in the $\mathrm{C} / \mathrm{NC}$ ratio with increasing depth. A traditional view has been that in a fluctuating environment the ability of an organism to exist in as wide as a range of habitats as possible and to have a wide trophic scope, is adaptative, whereas greater environmental stability leads to more specialisation. Thus niche width might be expected to be greater at shallower depths, with a corresponding increase in number of generalist species, i.e. non-carnivores (Valentine et al. 2002). The increase in number of carnivores with depth might respond to an increase of environmental stability with increasing depth. In addition, life history strategies, i.e. larval development, egg size, fecundity and mobility, have been reported as some of the causes affecting the rate of species turnover (Sanders and Grassle 1971; Allen and Sanders 1996; Cartes and Carrasson 2004). In summary, the bathymetric distribution of prosobranchs 
in the area of study may be explained by a combination of biological and physical factors.

\section{Diversity pattern}

In this study, depth was a significant predictor of diversity, explaining nearly a quarter the variance. There was a pattern of decreasing diversity downslope from $\sim 250 \mathrm{~m}$ to $\sim 1500-1600 \mathrm{~m}$, followed by an increase to high values at about $4000 \mathrm{~m}$ and then again, a fall to $\sim 4915 \mathrm{~m}$ (Figure 5a, b). However, this pattern differed from those observed for seastars and bivalves in the same area (Howell et al. 2002; Olabarria 2005). For example, in the case of seastars there were two diversity maxima at both $\sim 1800$ and $4700 \mathrm{~m}$ and a minimum at about $2600 \mathrm{~m}$. Bivalves presented a pattern of increasing diversity from $\sim 500$ to $1600 \mathrm{~m}$, followed by a decrease to minimum values at about $2600 \mathrm{~m}$. The depth-diversity pattern in this study did also differ from those found for other invertebrates elsewhere (e.g. Rex 1981, 1983; Patterson and Lambshead 1995; Rex et al. 1997; Flach and Bruin 1999; Gage et al. 2000). For example, across a bathymetric range from 0 to $5000 \mathrm{~m}$ for the NW Atlantic, Rex (1983) found a parabolic pattern in diversity with maxima at intermediate depths $(\sim 2000-3000 \mathrm{~m})$ for polychaetes, gastropods, protobranchs and cumaceans. Paterson and Lambshead (1995) also found a parabolic trend in diversity, peaking at about $1800 \mathrm{~m}$ for polychaetes at the Hebridean slope. Flach and Bruin (1999) found a slight increase of molluscs diversity with increasing depth in the Northeastern Atlantic. Gage et al. (2000) found a parabolic pattern in diversity of macrobenthos on the Scottish continental slope, with low values for the stations at about $400 \mathrm{~m}$, and higher values at around $1400 \mathrm{~m}$. Clearly, there is no global consistency in such patterns suggesting that processes structuring bathymetric patterns of prosobranch diversity in the Porcupine Seabight and adjacent Abyssal Plain are likely different, either in magnitude or type, from those operating in other Atlantic sites. In addition, these processes are likely different from those affecting other taxa in the same area (e.g. seastars, bivalves).

The low values of diversity found at about $1400-1600 \mathrm{~m}$ may be in part a result of high abundances $\left(\sim 3000\right.$ ind. $\left./ \mathrm{m}^{2}\right)$ of $B$. tenella. Both rarefaction method and Shannon diversity indices are largely dependent on sample size and patterns of species' distribution (Gray 2000). For example, the expected number of species occurring at this depth, based on a sample of 30 individuals (see Material and methods) is very low (Figure $5 b$ ). The use of such a low ES number might have overemphasised the decrease in diversity at this depth. Furthermore, the permanent thermocline from about 600 to $1400 \mathrm{~m}$ over which the temperature decreases from $\sim 10{ }^{\circ} \mathrm{C}$ to $\sim 4{ }^{\circ} \mathrm{C}$ (Rice et al. 1991) might cause the decrease of diversity with minimum values at $\sim 1400-1600 \mathrm{~m}$. The peak of diversity at $\sim 4000 \mathrm{~m}$ was previously found for 
bivalves in the West European Basin (Allen and Sanders 1996) and Porcupine Seabight region (Olabarria 2005). Flach and de Bruin (1999) also found high diversity values for molluscs at $\sim 4000 \mathrm{~m}$ in the Porcupine Seabight and Howell et al. (2002) reported increasing values of diversity for seastars in Porcupine Abyssal Plain from $\sim 4000$ to $4700 \mathrm{~m}$. Although the abyssal zone is thought to receive a low food input (e.g. Rex 1973; Flach and de Bruin 1999), several studies have reported strong fluxes of organic matter to the Porcupine Abyssal Plain (e.g. Thurston et al. 1998; Billett et al. 2001; Fabiano et al. 2001). Although seasonally variable, this supply of organic matter at abyssal depths might be in part responsible for the increase of diversity observed at $\sim 4000 \mathrm{~m}$ (Gili et al. 2000; Cartes et al. 2002; Olabarria 2005). Moreover, Rex et al. (2005) in their source-sink hypothesis proposed that many abyssal molluscan populations of North Atlantic might be maintained by immigration from adjacent bathyal populations of species with high dispersal ability. Therefore, source-sink dynamics might increase local diversity in the abyss and it might be particularly important in explaining the downslope patterns of diversity observed in this study.

In summary, turrids were the most diverse family with the broadest bathymetric range in the Porcupine Seabight and adjacent Abyssal Plain. The rate of species succession (addition and loss) increased rapidly with increasing depth and indicated four possible areas of faunal turnover at about 700 , 1600,2800 and $4100 \mathrm{~m}$. Depth was a significant predictor of diversity, explaining nearly a quarter the variance. There was a pattern of decreasing diversity downslope from $\sim 250 \mathrm{~m}$ to $\sim 1500-1600 \mathrm{~m}$, followed by an increase to high values at about $4000 \mathrm{~m}$ and then again, a fall to $\sim 4915 \mathrm{~m}$. In this study, the depth-diversity trend in prosobranchs differed from those patterns previously shown by other invertebrate groups in the same area or elsewhere. Clearly, there is no global consistency in such patterns suggesting they are more a reflection of local conditions than expressing any fundamental response to depth.

\section{Acknowledgements}

I would like to thank the officers and crews of RSS Challenger and RSS Discovery, as well as the colleagues who have been instrumental in collecting the samples used in this study. This research has been supported by a Marie Curie Fellowship of the European Community programme "Energy, Environment and Sustainable Development" under contract EVK2-CT-200150010 and an Isidro Parga Pondal Fellowship of the Galician Government to Celia Olabarria. In addition, I would also like to thank Dr McKindsey for his valuable comments on the first draft of this manuscript and two anonymous referees whose comments improved considerably the original manuscript. 


\section{References}

Allen J.A. and Sanders H.L. 1996. The zoogeography, diversity and origin of the deep-sea protobranch bivalves of the Atlantic: the epilogue. Prog. Oceanogr. 38: 95-153.

Billett D.S.M. 1991. Deep-sea holothurians. Oceanogr. Mar. Biol.: Annu. Rev. 29: 259-317.

Billett D.S.M., Bett B.J., Rice A.L., Thurston M.H., Galéron J., Sibuet M. and Wolff G.A. 2001. Long-term change in the megabenthos of the Porcupine Abyssal Plain (NE Atlantic). Prog. Oceanogr. 50: 325-348.

Bouchet P. and Warén A. 1980. Revision of the Northeast Atlantic bathyal and abyssal Neogastropoda excluding Turridae (Mollusca, Gastropoda). Boll. Malacol. 1: 1-294.

Bouchet P. and Warén A. 1985. Revision of the North-East Atlantic bathyal and abyssal Turridae (Mollusca, Gastropoda). J. Mollus. Stud. 8: 1-119.

Bouchet P. and Warén A. 1986. Revision of the northeast Atlantic bathyal and abyssal Aclididae, Eulimidae, Epitoniidae (Mollusca, Gastropoda). Boll. Malacol. 2: 1-570.

Bouchet P. and Warén A. 1993. Revision of the northeast Atlantic bathyal and abyssal mesogastropoda. Boll. Malacol. 3: 1-837.

Cartes J.E. and Carrason M. 2004. Influence of trophic variables on the depth-range distributions and zonation rates of deep-sea megafauna: the case of the Western Mediterranean assemblages. Deep-Sea Res. I 51: 263-279.

Cartes J.E., Grémare A., Maynou F., Villora-Moreno S. and Donet A. 2002. Bathymetric changes in the distributions of particulate organic matter and associated fauna along a deep-sea transect down the catalan sea slope (Northwestern Mediterranean). Prog. Oceanogr. 53: 29-56.

Clarke K.R. and Warwick R.M. 1998. A taxonomic distinctness index and its statistical properties. J. Appl. Ecol. 35: 523-531.

Clarke K.R. and Warwick R.M. 1999. The taxonomic distinctness measure of biodiversity: weighting of step lengths between hierarchical levels. Mar. Ecol. Prog. Ser. 184: 21-29.

Danovaro R., Dinet A., Duineveld G. and Tselepides A. 1999. Benthic response to particulate fluxes in different trophic environments: a comparison between the Gulf of Lions-Catalan Sea (western-Mediterranean) and the Cretan Sea (eastern-Mediterranean). Prog. Oceanogr. 44: $287-312$.

Dauvin J.C., Kendall M., Paterson G., Gentil F., Jirkov I. and Sheader M. 1994. An initial assessment of polychaete diversity in the northeastern Atlantic Ocean. Biodivers. Lett. 2: 171181.

Etter R.J. and Grassle J.F. 1992. Patterns of species diversity in the deep sea as a function of sediment particle size. Nature 360: 576-578.

Etter R.J. and Rex M.A. 1990. Population differentiation decreases with depth in deep-sea gastropods. Deep-Sea Res. I 37: 1251-1261.

Fabiano M., Pusceddu A., Dell'Anno A., Armen M., Vanucci S., Lampitt R.S., Wolf G.A. and Danovaro R. 2001. Fluxes of phytopigments and labile organic matter to the deep ocean in the NE Atlantic Ocean. Prog. Oceanogr. 50: 80-104.

Flach E. and de Bruin W. 1999. Diversity patterns in macrobenthos across a continental slope in the NE Atlantic. J. Sea Res. 42: 303-323.

Flach E., Lavaleye M., deStigter H. and Thomsen L. 1998. Feeding types of the benthic community and particle transport across the slope of a NW European continental margin (Goban Spur). Prog. Oceanogr. 42: 209-231.

Gage J.D., Lamont P.A., Kroeger K., Paterson G.L.J. and Gonzalez Vecino J.L. 2000. Patterns in deep-sea macrobenthos at the continental margin: standing crop. diversity and faunal change on the continental slope off Scotland. Hydrobiologia 440: 261-271.

Gage J.D., Lamont P.A. and Tyler P.A. 1995. Deep-sea macrobenthic communities at contrasting sites off Portugal. Preliminary results: I. Introduction and diversity comparisons. Int. Rev. Hydrobiol. 80: 235-250.

Gage J.D. and Tyler P.A. 1991. Deep-Sea Biology: A Natural History of Organisms at the DeepSea Floor. Cambridge University Press, Cambridge. 
Gambi C., Vanreusel A. and Danovaro R. 2003. Biodiversity of nematode assemblages from deepsea sediments of the Atacama Slope and Trench (South Pacific Ocean). Deep-Sea Res. I 50: $103-117$.

Gili J.M., Pagès F., Bouillon J., Palanques A., Puig P., Heussner S., Calafat A., Canals M. and Monaco A. 2000. A multidisciplinary approach to the understanding of hydromedusan populations inhabiting Mediterranean submarine canyons. Deep-Sea Res. I 47: 1513-1533.

Grassle J.F. and Maciolek N.J. 1992. Deep-sea species richness: regional and local diversity estimates from quantitative bottom samples. Am. Nat. 139: 313-341.

Grassle J.F. 1989. Species diversity in deep-sea communities. Trends Ecol. Evol. 4: 12-15.

Gray J.S. 2000. The measurement of marine species diversity, with an application to the benthic fauna of the Norwegian continental shelf. J. Exp. Mar. Biol. Ecol. 250: 23-49.

Hall S.J. and Greenstreet S.P.R. 1998. Taxonomic distinctness and diversity measures: responses in marine fish communities. Mar. Ecol. Prog. Ser. 166: 227-229.

Hill M.O. 1973. Diversity and evenness: a unifying notation and its consequence. Ecology 54: $427-432$.

Hooper J.N.A., Kennedy J.A. and Quinn R.J. 2002. Biodiversity "hotspots" patterns of richness and endemism, and taxonomic affinities of tropical Australian sponges (Porifera). Biol. Conserv. 11: 851-885.

Howell K.L. Billett D.S.M. and Tyler P.A. 2002. Depth-related distribution and abundance of seastars (Echinodermata: Asteroidea) in the Porcupine Seabight and Porcupine Abyssal Plain, N.E. Atlantic. Deep-Sea Res. I 49: 1901-1920.

Hurlbert S.M. 1971. The non-concept of species diversity, a critique and alternative parameters. Ecology 52: 577-586.

Lambshead P.J.D. 1993. Recent developments in marine benthic biodiversity research. Oceanis 19: $5-24$.

Lambshead P.J.D., Brown C.J., Ferrero T.J., Mitchell N.J., Smith C.R., Hawkins L.E. and Tietjen J. 2002. Latitudinal diversity patterns of deep-sea marine nematodes and organic fluxes: a test from the central equatorial Pacific. Mar. Ecol. Prog. Ser. 236: 129-135.

Olabarria C. 2005. Patterns of bathymetric zonation of bivalves in the Porcupine Seabight and adjacent Abyssal Plain, N.E. Atlantic. Deep-Sea Res. I 52: 15-31.

Paterson G.L.J. and Lambshead P.J.D. 1995. Bathymetric patterns of polychaete diversity in the Rockall Trough, north-east Atlantic. Deep-Sea Res. 42: 1199-1214.

Piepenburg D., Voß J. and Gutt J. 1997. Assemblages of sea stars (Echinodermata: Asteroidea) and brittle stars off Northeast Greenland (Arctic): a comparison of diversity and abundance. Polar Biol. 17: 305-322.

Rex M.A. 1973. Deep-sea species diversity: decreased gastropod diversity at abyssal depths. Science 181: 1051-1053.

Rex M.A. 1977. Zonation in deep-sea gastropods: the importance of biological interactions to rates of zonation. In: Keegan B.F., Ceidigh P.O. and Boaden P.J.S. (eds), Biology of Benthic Organisms. Pergamon Press, New York, pp. 521-530.

Rex M.A. 1981. Community structure in the deep-sea benthos. Annu. Rev. Ecol. Syst. 12: 331-353. Rex M.A. 1983. Geographic patterns of species diversity in the deep-sea benthos. In: Rowe G.T. (eds), The Sea, vol 8. Wiley, New York, pp. 453-472.

Rex M.A. and Etter R.J. 1990. Geographic variation in two deep-sea gastropods, Benthonella tenella (Jeffreys) and Benthomangelia antonina (Dall). Deep-Sea Res. II 45: 103-127.

Rex M.A., Etter R.J., Clain A.J. and Hill M.S. 1999. Bathymetric patterns of body size in deep-sea gastropods. Evolution 53(4): 1298-1301.

Rex M.A., Etter R.J. and Stuart C.T. 1997. Large-scale patterns of diversity in the deep-sea benthos. In: Ormond, R.F.G., Gage J.G. and Angel M.V. (eds.), Marine Biodiversity: Patterns and Processes. Cambridge University Press, Cambridge, pp. 94-121.

Rex M.A., McClain C.R., Johnson N.A., Etter R.J., Allen J.A., Bouchet P. and Warén A. 2005. A source-sink hypothesis for abyssal biodiversity. Am. Nat. 165: 163-178.

Rex M.A., Stuart C.T., Hessler R.R., Allen J.A., Sanders H.L. and Wilson D.F. 1993. Global-scale latitudinal patterns of species diversity in the deep-sea benthos. Nature 365: 636-639. 
Rex M.A., Van Ummersen C.A. and Turner R.D. 1979. Reproductive pattern in the abyssal snail Benthonella tenella (Jeffreys). In: Stancyk S.E. (ed.), Reproductive Ecology of Marine Invertebrates. University of South Carolina Press, pp. 173-188.

Rice A.L., Aldred R.G., Darlington E. and Wild R.A. 1982. The quantitative estimation of the deep-sea megabenthos - a new approach to an old problem. Oceanol. Acta 5: 63-72.

Rice A.L., Billett D.S.M., Thurston M.H. and Lampitt R.S. 1991. The Institute of oceanographic sciences biology programme in the Porcupine Seabight: background and general introduction. J. Mar. Biol. Assoc. UK 71: 281-310.

Rogers S.I., Clarke R.K. and Reynolds J.D. 1999. The taxonomic distinctness of coastal bottomdwelling fish communities of the North-east Atlantic. J. Anim. Ecol. 68: 769-782.

Rosenberg G. 1998. A classification of the Mollusca. http://erato.cnatsci.org/conchnet/classify. html.

Sanders H.L. 1968. Marine benthic diversity: a comparative study. Am. Nat. 102: 243-282.

Sanders H.L. and Grassle J.F. 1971. The interactions of diversity, distribution and mode of reproduction among major groupings of the deep-sea benthos. In: Uda M. (ed.), The Ocean World: Proceedings of Joint Oceanographic Assembly. Japan Society for the Promotion of Science, Tokyo, pp. 260-262.

Thurston M.H., Rice A.L. and Bett B.J. 1998. Latitudinal variation in invertebrate megafaunal abundance and biomass in the North Atlantic Ocean Abyss. Deep-Sea Res. II 45: 203-224.

Tsurumi M. and Tunnicliffe V. 2003. Tubeworm-associated communities at hydrothermal vents on the Juan de Fuca Ridge, northeast Pacific. Deep-Sea Res. I 50: 611-629.

Valentine J.W., Roy K. and Jablonski D. 2002. Carnivore/non-carnivore ratios in northeastern Pacific marine gastropods. Mar. Ecol. Prog. Ser. 228: 153-163.

Warwick R.M. and Clarke K.R. 1995. New "biodiversity" measures reveal a decrease in taxonomic distinctness with increasing stress. Mar. Ecol. Prog. Ser. 129: 301-305.

Williams P.H., Humphries C.J. and Vane-Wright R.I. 1991. Measuring biodiversity: taxonomic relatedness for conservation priorities. Aust. Syst. Bot. 4: 665-679.

Woodd-Walker R.S., Ward P. and Clarke A. 2002. Large-scale patterns in diversity and community structure of surface water copepods from the Atlantic Ocean. Mar. Ecol. Prog. Ser. 236: 189-203. 